\title{
UPAYA GURU DALAM PENGUATAN NILAI KARAKTER SISWA MELALUI PEMBELAJARAN AQIDAH AKHLAK DI MIS ASSALAM KEC. MONTA KAB. BIMA
}

\author{
Abd. Salam \\ Sekolah Tinggi Ilmu Tarbiyah (STIT) Sunan Giri Bima \\ Email: salamrahmania1234@yahoo.co.id
}

\begin{abstract}
Abstrak:
Proses pembelajaran yang dilaksankan para guru seyogyanya dapat menciptakan suasana belajar yang menyenangkan sehingga siswa dapat tersenyum, senang serta menunjukan sikap partisipatif dalam mengikuti kegitan pembelajaran. Sedangkan pada sisi yang lain, proses pembelajaran juga harus diarahkan pada penguatan nilai-nilai karakter bagi perkembangan pribadi seorang siswa. Dalam konteks ini, guru di Madrasah Ibtidaiyah (MI) khususnya para guru bidang studi aqidah akhlak sangat dituntut untuk mengedapankan nilai-nilai karakter bagi peserta didiknya/siswa sebagai wujud capaian akhir pembentukan moral dan akhlak seorang anak didik. Berkenaan dengan hal tersebut, penelitian ini bertujuan untuk mengkaji; Bagaimana upaya guru dalam penguatan nilai-nilai Karakter siswa melalui pembelajaran bidang studi aqidah akhlakdi MIS Assalam Desa Wilamaci Kec. Monta Kab. Bima.
\end{abstract}

Kata kunci : Penguatan Nilai-nilai Karakter, Aqidah Akhlak.

\section{PENDAHULUAN}

ecerdasan guru dalam menjadikan pelajaran sebagai hiburan. Jadi cara
mengajar guru harus menciptakan suasana belajar yang menyenangkan serta tidak membosankan. Kesabaran guru pgmi dalam menciptakan suasana belajar yang sesuai dengan situasi siswa dizaman naow, kebiasaan dan bahasa siswa disaat ini tentu guru pgmi mengkondisikan mengajarnya dengan perputaran zaman. Oleh karena itu, guru harus mampu membuat siswa itu terhibur dengan cara mengajarnya, maka sudah barang tentu siswa akan meminta terus-menerus kepada guru tersebut yang mengajarnya dan satu-satunya guru yang dipuji dan sukai. Guru sebagai salah satu unsur dibidang pendidikan harus berperan aktif dan menempatkan kedudukan sebagai tenaga profesional, sesuai dengan tuntutan masyarakat yang semakin berkembang, hal ini dapat di artikan bahwa pada setiap guru terletak tanggung jawab untuk membawa para siswa kepada suatu kedewasaan atau taraf pematangan tertentu dalam rangka ini, guru tidak semata- 
mata sebagai pengajar yang hanya mentransfer ilmu pengetahuan, tetapi juga sebagai pendidik dan pembimbing yang memberikan pengarahan dan menuntun siswa dalam belajar. (Hadari Nawawi, 2015: 123). Pendidikan karakter akhir-akhir ini semakin banyak diperbincangkan di tengah-tengah masyarakat Indonesia, terutama oleh kalangan akademisi.Sikap dan perilaku masyarakat dan bangsa Indonesia sekarang cenderung mengabaikan nilai-nilai luhur yang sudah lama dijunjung tinggi dan mengakar dalam sikap dan perilaku sehari-hari. Nilai-nilai karakter mulia, seperti kejujuran, kesantunan, kebersamaan, dan religius, sedikit demi sedikit mulai tergerus oleh budaya asing yang cenderung hedonistik, materialistik, dan individualistik, sehingga nilai-nilai karakter tersebut tidak lagi dianggap penting jika bertentangan dengan tujuan yang ingin diperoleh.

Anas Salahudin dan Irwanto Alkrienciehie, mengatakan dalam buku Pendidikan Karakter, Pendidikan berbasis Agama dan Budaya Bangsa Menurut ajaran Islam, hakikat pendidikan adalah mengembalikan nilainilai ilahiah pada manusia (fitrah)dengan bimbingan Al-Qur'an dan AsSunnah (hadits) sehingga menjadi manusia yang berakhlak mulia. ( Irwanto Alkrienciehie, 2013: 49).

Berdasarkan tujuan dari penguatan karakter pada pembelajaran aqidah akhlak tersebut, yaitu berupaya membentuk watak manusia yang memiliki sikap mental dan prilaku yang baik (akhlaqul karimah), manusia yang bermoral dan memiliki etika serta sopan santun, baik terhadap diri pribadi Santri-Santriwati, orang lain, lingkungan. Aqidah merupakan keyakinan hati nurani manusia yang pasti datangnya dari Allah Swt, dan harus dipercayai kebenarannya. Jika penulis teliti secara mendalam bisa dikatakan bahwa kepribadian muslim adalah suatu pengertian yang mendasari perbuatan seseorang. Dengan demikian aqidah perlu dipahami secara tepat dan benar dan diamalkan dalam kehidupan sehari-hari sebagai refleksi taqwa kepada Allah Swt. Untuk mencapai hal tersebut maka guru bidang studi aqidah akhlak perlu melaksanakan dan mengajarkan pada siswa secara tepat dan benar, sesuai dengan perkembangan anak.

\section{TINJAUAN TEORITIS}

\section{Hakikat Profesi Guru}

Guru adalah sebuah profesi, sebagaimana profesi lainnya merujuk pada pekerjaan atau jabatan yang menuntut keahlian, tanggung jawab, dan kesetiaan. Suatu profesi tidak bisa dilakukan oleh sembarang orang yang tidak dilatih atau dipersiapkan untuk itu. Sebagai sebuah profesi, guru bekerja berdasarkan payung 
hukum. Pada Undang-undang No. 14 tahun 2005 tentang Guru dan Dosen (pasal 1, butir 1), menyebutkan bahwa guru adalah pendidik profesional dengan tugas utama. Walaupun guru sudah dianggap sebagai profesi dan bukan pekerjaan sambilan, tanggung jawab untuk mencerdaskan anak bangsa melalui pendidikan karakter menjadi tantangan tersendiri bagi guru.Memang tidak mudah. Aral atau rintangan di depan mata seolah menggiurkan hasrat untuk bersenang-senang. Sebab, dengan menjadi suatu profesi, guru sekarang lebih mendapatkan kehidupan yang lebih layak. Materi, penghasilan yang menjanjikan adalah tantangan kehidupan dikemudian hari.

Sosok guru profesional ini, tentu saja harus didahului dengan rumusan kita tentang konsep profesionalisme itu sendiri. Kriteria normatif yang umumnya dituntut dari seorang guru sebagai suatu profesi. Ciri-ciri keprofesionalan itu, antara lain: (1) masyarakat mengakui layanan yang diberikan atas dasar dimilikinya seperangkat ilmu dan keterampilan yang mendukung profesi itu; (2) diperlukan adanya proses pendidikan tertentu sebelum seseorang dapat/ mampu melaksanakan tugas profesi tersebut; (3) dimilikinya mekanisme seleksi standar, sehingga hanya mereka yang kompeten boleh melakukan pekerjaan/ profesi itu; dan (4) dimilikinya organisasi profesi untuk melindungi kepentingan anggotanya serta meningkatkan layanan kepada masyarakat, termasuk adanya kode etik profesi sebagai landasan perilaku keprofesionalannya (Westly Gibson dalam Mulyasa, 2007: 8)

Menurut Undang-Undang nomor 20 tahun 2003 tentang Sistem Pendidikan Nasional Pasal 1, mengenai ketentuan umum butir 6, pendidik adalah tenaga kependidikan yang berkualifikasi sebagai guru, dosen, konselor, pamong belajar, widyaiswara, tutor, instruktur, fasilitator, dan sebutan lain yang sesuai dengan kekhususannya, serta berpartisipasi dalam menyelenggarakan pendidikan. Dengan kata lain, dapat dikatakan bahwa guru adalah pendidik. Menurut Kamus Besar Bahasa Indonesia yang dimaksud dengan guru adalah orang yang pekerjaannya (mata pencahariannya, profesinya) mengajar. Pengertian guru menurut KBBI di atas, masih sangat umum dan belum bisa menggambarkan sosok guru yang sebenarnya, sehingga untuk memperjelas gambaran tentang seorang guru diperlukan definisi-definisi lain.

Nurdin mengungkapkan hal yang berbeda tentang pengertian guru. Menurutnya guru dapat diartikan sebagai orang yang tugasnya terkait dengan upaya mencerdaskan kehidupan bangsa dalam semua aspeknya, baik spiritual dan emosional, intelektual, fisikal, maupun aspek lainnya. Ia 
juga menambahkan bahwa secara legal formal, guru adalah seseorang yang memperoleh surat keputusan (SK), baik dari pemerintah maupun pihak swasta untuk mengajar. (Nurdin, 2002: 12-13).

Selanjutnya menurut Mc. Leod sebagaimana dikutip oleh Trianto bahwa guru adalah "A person whose occupation is teaching others, artinya ialah seseorang yang tugas utamanya adalah mengajar" (Muhibbin Syah, 2002: 222). Demikian juga menurut Mulyasa (2006:37), menjelaskan bahwa istilah guru adalah pendidik yang menjadi tokoh, panutan dan identifikasi para peserta didik dan lingkungannya, karena itulah guru harus memiliki standar kualitas pribadi tertentu yang mencakup tanggung jawab, wibawa, mandiri dan disiplin.

Berdasarkan ragam uraian pendapat tentang guru di atas, dapat disimpulkan bahwa guru adalah seseorang yang telah memperoleh surat keputusan (SK), untuk menggeluti profesi yang memerlukan keahlian khusus dalam tugas utamanya untuk mengajar dan mendidik siswa pada pendidikan anak usia dini jalur pendidikan formal, pendidikan dasar, dan menengah, yang tujuan utamanya untuk mencerdaskan bangsa dalam semua aspek.

\section{Konsep Dasar Karakter dan Pembelajaran Aqidah Akhlak}

Secara etimologis, kata karakter (Inggris: character) berasal dari bahasa Yunani (Greek), yaitucharassein yang berarti "to engrave" (Kevin Ryan dan Karen E. Bohlin, 1999: 5). Kata "to engrave" bisa diterjemahkan mengukir, melukis, memahatkan, atau menggoreskan (Echols dan Shadily, 1987: 214).

Dalam Kamus Bahasa Indonesia kata "karakter" diartikan dengan tabiat, sifat-sifat kejiwaan, akhlak atau budi pekerti yang membedakan seseorang dengan yang lain, dan watak.Karakter juga bisa berarti huruf, angka, ruang, simbul khusus yang dapat dimunculkan pada layar dengan papan ketik (Pusat Bahasa Depdiknas, 2008: 682). Orang berkarakter berarti orang yang berkepribadian, berperilaku, bersifat, bertabiat, atau berwatak.Dengan makna seperti ini berarti karakter identik dengan kepribadian atau akhlak.Kepribadian merupakan ciri atau karakteristik atau sifat khas dari diri seseorang yang bersumber dari bentukan-bentukan yang diterima dari lingkungan, misalnya keluarga pada masa kecil, dan juga bawaan sejak lahir (Doni Koesoema, 2007: 80).

Sementara dalam tinjauan terminologis, makna karakter dikemukakan oleh Thomas Lickona.Menurutnya karakter adalah "A reliable inner disposition to respond to situations in a morally good way. "Selanjutnya Lickona menambahkan, "Character so conceived hasthree interrelated parts: moral knowing, moral feeling, and moral behavior" (Lickona, 1991: 51). Menurut Lickona, karakter mulia (good character) meliputi pengetahuan tentang kebaikan, lalu menimbulkan 
komitmen (niat) terhadap kebaikan, dan akhirnya benar-benar melakukan kebaikan. Dengan kata lain, karakter mengacu kepada serangkaian pengetahuan (cognitives), sikap (attitides), dan motivasi (motivations), serta perilaku (behaviors) dan keterampilan (skills).

Dari pengertian di atas dapat dipahami bahwa karakter identik dengan akhlak, sehingga karakter merupakan nilai-nilai perilaku manusia yang universal yang meliputi seluruh aktivitas manusia, baik dalam rangka berhubungan dengan Tuhannya, dengan dirinya, dengan sesama manusia, maupun dengan lingkungannya, yang terwujud dalam pikiran, sikap, perasaan, perkataan, dan perbuatan berdasarkan norma-norma agama,hukum, tata karma, budaya, dan adat istiadat. Dari konsep karakter ini muncul konsep pendidikan karakter (character education).

Sedangkan Pembelajaran Bidang studi aqidah akhlak adalah sub bidang studi pada jenjang pendidikan dasar yang membahas ajaran Islam dari segi aqidah dan akhlak. Bidang studi aqidah akhlak juga merupakan bagian dari mata pelajaran pendidikan agama Islam yang memberikan bimbingan kepada siswa agar memahami, menghayati, menyakini ajaran Islam serta bersedia mengamalkannya dalam kehidupan sehari-hari. (Departemen Agama RI,1999: 1) Aqidah akhlak membahas masalah ketuhanan yang secara terperinci di kenal dengan rukun Iman yang terdiri dari enam bagian yaitu : (1) Iman kepada Allah, (2) Iman kepada Malaikat, (3) Iman kepada Rasul-Nya. (4) Iman kepada Kitabkitab-Nya, (4) Iman kepada hari kiamat, (5) Iman kepada Qada dan Qadar.

Menurut Ruddin Emang dan Lomba Sultan (1995:13) bahwa keenam ajaran pokok Islam tersebut dimaksudkan agar nilai keimanan pada manusia mempunyaikesatuan dalam memahami ma'rifat sebagai inti dari aqidah. Aqidah yang mantap dapat menimbulkan akhlak yang terpuji. Materi pelajaran guru bidang studi aqidah akhlak, diharapkan dapat menyajikan pendidikan terhadap anak didik dalam menempuh dan menelusuri berbagai kehidupan yang berbelitbelit dalam hal memantapkan keyakinan, serta bertujuan untuk memiliki dan memperbaiki akhlak atau budi pekerti yang bisa dipraktekkan dalam kehidupan sehari-hari. Hal tersebut dikemukakan bahwa Budi pekerti adalah sikap hidup atau karakter atau perangai yang diperoleh melalui latihan atau kesanggupan mengendalikan diri di mulai latihan dengan sadar akan yang baik adalah baik tingkah laku yang baik dan yang buruk adalah dilakukannya berbuat baik dan 
penuh kesadaran dan akhirnya menjadilah adat kebiasaan yang tidak mungkin lagi berbuat jahat.

\section{METODE PENELITIAN}

Peneliti ini merupakan penelitian lapangan dengan menggunakan penedekatan kualitatif yaitu suatu penelitian yang ditujukan untuk mendeskripsikan dan menganalisis fenomena, peristiwa, aktivitas sosial, sikap, kepercayaan, persepsi, pemikiran orang secara individual maupun kelompok. ${ }^{1}$ penelitian dilaksanakan di Madrasah Ibtidaiyah Swasta (MIS) Assalam Desa Wilamaci Kec. Monta Kab.Bima.

Selanjutnya data yang diperoleh dari hasil penelitian dinalisis dengan menggunakan teknik deskriptif analitik, yaitu data yang diperoleh tidak dianalisa menggunakan rumusan statistika, namun data tersebut didetesiskan sehingga dapat memberikan kejelasan sesuai kenyataan realita yang ada di lapangan. Pada tahap ini, proses analisa melalui beberapa langkah anatra lain: reduksi data (data reduction), penyajian data (data display), dan penarikan kesimpulan (conclusion). (Sugiyono, 2009: 92). Penggunaan metode analisis dan interpretasi bertujuan memberikan penjelasan secara deskriptif agar membantu pembaca mengetahui apa yang terjadi di lingkungan pengamatan terutama yang berkaiatan dengan upaya guru dalam penguatan nilai-nilai karakter siswa melalui pembelajaran bidang studi aqidah akhlak di MIS Assalam Desa Wilamaci Kec. Monta Kab. Bima.

\section{HASIL PENELITIAN DAN PEMBAHASAN}

\section{Gambaran Umum Lokasi Penelitian}

MIS Assalam Desa Wilamaci Kec. Monta Kab. Bima didirikan pada tahun 2014. MIS Assalam juga dikenal dengan nama Madrasa Ibtidaiyah/MI sebagai pusat penyelenggaran pendidikan dasar yang berbasis nilai-nalai yang berada di Desa Wilamaci Kec. Monta Kab. Bima. Bahkan. Dalam proses perkembangannya MIS Assalam belum mengalami perkembangan yang signifikan. Tapi MIS Assalam sebagai sekolah rintisan swasta secara bertahap sudah mengalami perkembangan yang cukup baik saat ini. Kondisi tersebut, dikeranakan adanya faktor sinergisitas kerja yang terkoordinasi antara Kepala Sekolah dan Guru MIS Assalam dalam menjalankan tugasnya. Dalam hal capaian pembelajaran, manajemen MIS Assalam Desa Wilamaci memiliki Visi yang unggul yakni menjadi sekolah Terdidik, Trampil, dan Mandiri berdasarkan Iman dan Taqwa adapun Misi MIS Assalam Desa Wilamaci sebagai berikut: 
a. Menerapkan pelaksanaan KBM yang intensif dan bermutu

b. Membiasakan berbudi pekerti luhur berdasarkan keimanan dan ketaqwaan

c. Menciptakan sekolah dan kondisi sejuk, aman, nyaman, dan kondusif

\section{Upaya guru dalam Penguatan Nilai-nilai Karakter siswa melalui pembelajaran Aqidah Akhlak di MIS Assalam Desa Wilamaci Kec. Monta Kab. Bima}

Penguatan nilai-nilai karakter dalam diri siswa/peserta didik dapat diupayakan melalui pembelajaran bidang studi aqidah akhlak. Proses pembeljaran aqidah akhlak, pada hakikatnya beruhan memberikan penguatan dasar terkait moral dan budi pekerti bagi perilaku seoreang siswa/anak didik di setiapa tingakkat satuan pendidikan. Berkenaan dengan hal tersebut, temuan penelitian bahwa proses penguatan nilai-nilai karakter siswa melalui pembelajaran aqidah akhlak di MIS Assalam Desa Wilamaci Kec. Monta Kab. Bima sangat menekankan aspek kualitas dan kuantitas dalam diri seorang anak didik dalam mengembangkan karakternya. Secara konsep, penguatan nilai-nilai karakter siswa melalui pembelajaran aqidah akhlak di MIS Assalam Desa Wilamaci Kec. Monta Kab. Bima terdapat kecenderungan para guru dalam mengajarkan para siswa/amak didik agar menginternalisasi dan mempertahankan nilai-nilai karakter yang sudah ada seperti; nilai religius, nilai Integritas, nilai nasionalis, nilai nandiri, nilai gotong goyong, nilai sabar dalam megikuti kegiatan pembelajaran. Kondisi inilah yang dibiasakan, dalam keseharian aktivitas pembelajaran siswa di MIS Assalam Desa Wilamaci Kec. Monta Kab. Bima. Adapun penjabaran bentuk pengauatan nilai-nilai karakter melalui Pembelajaran Aqidah Akhlak yakni sebagai berikut:

\section{Penguatan Nilai Religius}

a. Membumikan Al-Qur'an dengan cara magrib mengaji sesuai dengan program pemerintah kota bima

b. Membiasakan anak untuk berdoa sebelum dan sesudah baca Al-qur'an

c. Menugaskan anak untuk menghafal ayat-ayat pendek dan menyetorkan hafalanya setiap hari jum'at

d. Melakukan yasinan bersama pada setiap malam jum'at

e. Mengajak anak untuk sholat berjamaah di masjid/musholla

f. Memberikan contoh dan teladan yang baik dengan melakukan sholat dan mengaji 
g. Mengontrol anak agar sholat tepat waktu (membiasakan anak menghargai waktu).

\section{Penguatan Nilai Integritas}

a. Mengajarkan anak untuk berbicara apa adanya dan tidak suka bohong

b. Mengajarkan anak untuk mengakui kesalahan bila telah berbuat salah

c. Menunjukan pada anak tentang sikap jujur baik pada diri sendiri, keluarga dan orang lain yang didasarkan pada: bila berkata tidak bohong, bila berjanji tidak ingkar dan bila dipercaya harus bertanggung jawab

d. Menanamkan sikap jujur kepada anak harus diimbangi dengan perbuatan yang menjadi penilaian bagi diri sendiri dan menjadi contoh teladan bagi orang lain

e. Mengajarkan untuk selalu mengatakan sesuatu yang benar sekalipun pahit

f. Mengajarkan pada anak yang benar akan tetap dan yang benar akan mengantarkan orang untuk dipercaya

g. Membiasakan anak untuk memegang teguh pada komitmen dan tanggung jawab.

\section{Penguatan Nilai Nasionalis}

a. Menanamkan nilai kebangsaan kepada anak, bangga menjadi orang Indonesia lebih khusus orang bima

b. Menanamkan nilai rela berkorban sebagai anak bangsa Indonesia, mengutamakan kepentingan bangsa dan negara, di atas kepentingan induvidu dan golongan

c. Mengisi kemerdekaan dengan berbuat yang bermanfaat untuk bangsa dan negara dan diri sendiri

d. Setiap hari besar seperti hari pahlawan, proklamasi kemerdekaan anak-anak dibimbing untuk mengenang jasa pahlawan dan mendoakan, semoga arwahnya diterima disisi Allah SWT

e. Mengajarkan pada anak untuk mengikuti upacara

f. Mengajarkan kepada anak untuk memelihara semangat, tekad, disiplin

g. Mengajarkan kepada anak untuk mengikuti gerakan pramuka.

\section{Penguatan Nilai Mandiri}

a. Anak ditanamkan sikap patriotisme, ini harus terintegrasi dalam sikap dan kepribadian sebagai pribadi yang jujur, setia, suka menolong, dan berani menolak jika ada yang salah atau tidak benar

b. Berikan penghargaan pada anak jika dia berprestasi baik di sekolah maupun di lingkungan masyarakat khususnya di Tpq Al-Khairat Ling. Rasabou Kel. Jatibaru Kec. Asakota Kota Bima 
c. Tidak ada kata terlambat dalam belajar

d. Membiasakan bekerja dengan jujur, amanah sesuai dengan perintah

e. Menanamkan sikap untuk mengutamakan kepentingan umum dari pada kepentingan pribadi dan golongan

f. Guru ngaji mengajarkan pada anak untuk berbuat baik

g. Guru ngaji mengajarkan pada anak untuk bekerja seperti berkebun dihalaman rumah, dan membersihkan rumah.

\section{Penguatan Nilai Gotong Royong}

a. Mendatangi rumah/tempat kegiatan sohibul hajat, tetangga yang sakit

b. Memberikan dukungan/bantuan sesuai kebutuhan dan kesepakatan

c. Melibatkan diri pada kegiatan kemasyarakatan untuk meringankan bebanya

d. Menghidupkan kembali budaya atau saling membantu tanpa upah

e. Membersihkan tempat pemakan umum

f. Membersihkan tempat-tempat ibadah, saluran air dilingkungan sekitar

g. Melibatkan diri secara sadar atau saling membantu dalam memakamkan warga yang meninggal dunia

\section{Penguatan Nilai sabar dalam belajar}

Dengan adanya nilai-nilai pada guru dan siswa di atas maka penulis merumuskan nilai-nilai karakter yang dimiliki oleh guru dan siswa adalah nilai yang tidak dapat dipisahkan dalam jiwa. Jadi karater siswa sudah dilandasi dengan nilai-nilai Nilai Religius, Nilai Integritas, Nilai Nasionalis, Nilai Mandiri, Nilai Gotong Royong, Nilai sabar belajar. Nilai tersebut ibaratkan kulit dengan daging. Sehingga dalam sikap sudah menjadi kepribadian guru dan siswa dalam kehidupan sehari-hari. Penguatan nilai-nilai karakter secara istiqomah dan berakhlak mulia. Kendati demikian, dengan sendirinya akan menjadi penyelamat serta dapat menghidupkan kembali nilai-nilai karakter peserta didik.

\section{SIMPULAN}

Berdasarkan pembahasan dapat disimpulkan bahwasanya upaya guru dalam penguatan nilai-nilai karakter siswa melalui pembelajaran bidang studi aqidah akhlak di MIS Assalam Desa Wilamaci Kec. Monta Kab. Bima sebagai pembinaan karakter baik itu aqidahnya maupuan akhlak siswa/peserat didik sangatlah penting dilakukan pada setiap jenjang lembaga pendindikan, agar 
seorang siswa-siswi memiliki kepribadian yang baik dan terhindar dari pelanggaran-pelanggaran moral, maka perlu adanya penguatan nilai-nilai karakter siswa/anak didik sejak dini. Di sisi lain perlu adanya kerja sama guru dengan orang tua siswa dan masyarakat dalam merumuskan dan mengawal pembinaan perilaku seorang siswa. Bersama dengan itu pula, seorang siswa/anak didik juga dibimbing dengan nilai-nilai rohani, seperti cara tutur kata yang baik, berpakaian yang baik, bergaul dengan baik, dan lain-lain. Selain itu, peserta didik juga ditanamkan sifat-sifat yang baik, seperti nilai-nilai nilai religius, nilai integritas, nilai nasionalis, nilai mandiri, nilai gotong royong, nilai sabar dalam belajar pada setiap tingkat satuan pendidikan.

\section{DAFTAR PUSTAKA}

Anas Salahudin, Irwanto Alkrienciehie. 2013. Pendidikan Karakter, Pendidikan Berbasis Agama dan Budaya Bangs. Bandung Pustaka Setia.

Departemen Agama RI. 1999. Garis Besar Program Pengajaran (GBPP) Madrasah Tsanawiyah (MTsN). Jakarta : Dirjen Pembinaan Kelembagaan Agama Islam.

Ibrahim dan Nana Sudjana. 1989. Penelitian dan Penelitian Kualitatif. Bandung: Sinar Baru.

John M. Dan Hassan Shadily Echolis. 1987. Kamus Inggris Indonesia.Jakarta: Gramedia.

Kevin Ryan dan Karen E. Bohlin. 1999. Buliding Character in Schools: Pratical Ways to Bring Moral Instruction to Life. San Francisco: Jossey Bass.

Koesoema A Doni. 2007. Pendidikan Karakter: Strategi Mendidik Anak di Zaman Global. Jakarta: Grasindo.

Mulyasa. 2007. Menjadi guru profesional; Menciptakan pembelajaran kreatif dan menyenangkan. Bandung: Rosdakarya.

Mulyasa. 2006. Menjadi guru profesional. Bandung: PT Rosdakarya.

Madyawati Lilis. 2016. Strategi Pengembangan Bahasa Pada Anak. Jakarta: Pernadamedia Group.

Nawawi Hadari. 2015. Organisasi Sekolah dan Pengelolaan Kelas Sebagai Lembagas Pendidikan. Jakarta: CV. Haji Masagung.

Nurdin. 2002. Guru profesional dan Implementasi kurikulum. Jakarta: Ciputat Pers.

Pusat Bahasa Departemen Pendidikan Nasional. 2008. Kamus Bahasa Indonesia. Jakarta: Pusat Bahasa.

Ruddin Emang dan Lomba Sultan. 1995. Akhlak Tasawuf. Ujung Pandang : t.p. 
Sugiyono. 2009. Metode Penelitian Pendidikan Pendekatan Kuantitatif, Kualitatif dan $R \& D$. Bandung: Alfabeta.

Sudjana Nana, dan Ibrahim. 1989. Penelitian dan Penelitian Kualitatif. Bandung : Sinar Baru.

Syah Muhibbin. 2000. Psikologi pendidikan dengan pendekatan baru Edisi Revisi .Bandung: PT. Remaja Rosdakarya.

Thomas Lickona. 1991. Educating For Character: How Our School Can Teach Respect and Responsibility. Now York, Toronto, London, Sydney, Aucland: Bantam books, 1991. 